TAO, Vol. 16, No. 1, I-V, March 2005

\title{
Preface to the Special Section on Okinawa Trough: Sedimentary Processes and Paleoenvironment
}

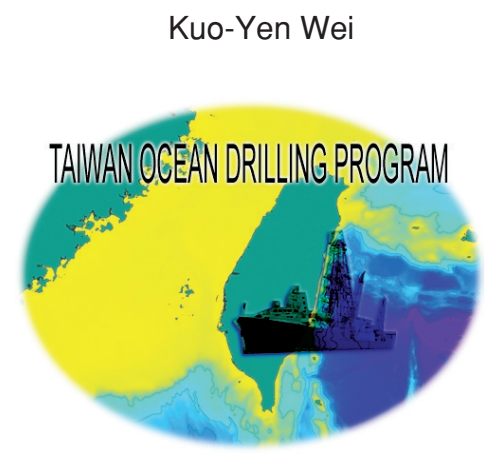

During 2001 Ocean Drilling Program (ODP) Leg 195 drilled four holes at Site 1202 off northeast Taiwan (Salisbury et al. 2002). The water depth is $1274 \mathrm{~m}$ and the site is located at a gentle topographic high in the bottom of the southern continental slope of the southern Okinawa Trough. The main theme of this special issue is to report and summarize the latest important results derived mainly from the studies of Site ODP1202.

Despite its long history since 1968, the international scientific ocean drilling program has not visited the Okinawa Trough until 2001 when the JOIDES Resolution entered this marginal sea for the first time and drilled ODP 1202 site during Leg 195. From the four holes a total of 765 meters of cores were retrieved. These long cores provide an opportunity for us to probe into the geological history of the Okinawa Trough recorded in the sediments.

The site ODP 1202 was originally designed as a contingent site to be added on for ODP Leg 195 if the two previously scheduled sites (Sites 1200 and 1201) were smoothly occupied in time. The design of this site is credited to a group of geoscientists of Taiwan, led by KuoYen Wei, Min-Te Chen and Char-Shine Liu, who proposed in 2000 to drill this site as a mean to probe into late Quaternary paleoceanographic records of the Kuroshio. Fortunately, the idea was well received by the Evaluation Science Steering Panel of the ODP, and the drilling was realized quickly in the next year.

As expected, sedimentary cores at this site hold a great deal of information relating not only to the nature of sedimentation in the southern Okinawa Trough but also the paleoenvironmental changes of adjacent lands and oceans. Unexpected, however, is that the sedimentation rates here have been extremely high, resulting in an unprecedented high-resolution record: the 408 meter long cores record only a history of the past 68 thousand years (see Wei et al. 2005), the temporal resolution theoretically can amount to as high as 1.7 years per $\mathrm{cm}$ of sediments! Enormous input of sediments from adjacent mainland China and from Taiwan is the main reason for the observed high sedimentation rate. However, part of the sedimentation was manifested in the form of turbidites, particularly for the interval between $175 \mathrm{~m}$ to $325 \mathrm{~m}$ below the seafloor (Huang et al. 2005). There detailed examination of the sedimentary cores revealed that the upper $130 \mathrm{~m}$ of the cores does not contain any discernable layers of turbidity-current laid sediments, whereas the lower sections are enriched with frequent and 
thick turbidite deposits. Frequent interruptions of turbidite layers in the lower sections of the sediment records were recognized by shipboard scientists during the cruise. Shore-based research has thus been suggested to focus on the top 120 meters of the record if the paleoenvironmental history is the main thrust of the research goal. It turns out that all of the high-resolution studies so far have been conducted on the top 120 meters of Hole B, an interval free of turbidite disturbance.

This special issue serves virtually as a "Proceeding Volume" of the early days' Deep Sea Drilling Project, reporting preliminary results of various aspects of the ODP Site 1202. A brief account is given below as an annotated guide.

Huang et al. conducted a very detailed, quantitative description of all the cores of Holes B and D. All the visible turbidite structures, such as occurrence of silt/sand layer, grain size grading, basal erosion, cross-ripples, detritus composition, and re-deposited shallow-water microfossils were noted. The detailed descriptions of individual cores of Hole D were presented graphically with 41 figures. In addition, the thickness percentage of silt/sand layers in every $1.5 \mathrm{~m}$ long core was calculated and graphically summarized. The sandy fractions of the turbidites are mainly composed of slate fragments, quartz, mica flakes and volcanic grains. Microfossils, if present, are almost all displaced shelf biota, including benthic foraminifers, echinoderm plates and spines, and mollusc. This paper presents an indispensable basis for any further detailed analyses of the cores.

Equally important is the contribution by Wei et al., who provided a chronostratigraphic scheme for Holes B and D based upon oxygen isotopic ratio profiles of planktonic foraminifera Neogloboquadrina dutertrei. The upper part of the $\delta^{18} \mathrm{O}$ profile can be well correlated to that of central Okinawa Trough site DGKS9603 (Li et al. 2001) in both trend and absolute values whereas the lower part is considered to belong to marine oxygen isotope stage 4 by correlating to MD972142 in the South China Sea (Wei et al. 2003). The bottom of Hole D of ODP1202 is estimated to be no older than $68 \mathrm{ka}$. The resultant correlation is also supported by Chang et al (2005) who correlated the oxygen isotope stratigraphy of Site 1202 with that in a newly studied site MD 12404 of the central Okinawa Trough. To make a complete stacked record of ODP1202, the upper sections of Hole D was correlated with Hole B using observable lithological characters, physical parameters (magnetic susceptibility and density measured by MST) by Wei et al. Similar efforts were made to correlate Hole A with Hole B and the results were presented in Jean et al. For the top of 120 meters of Hole B, Wei et al. constructed an age model furnished with 11 carbon-14 dating points. The sedimentation rates are relatively high, varying between 1.5 and $9 \mathrm{~m} \mathrm{ky}^{-1}$ during the past $28 \mathrm{kyrs}$.

Three papers in this issue address particularly the paleoceanographic aspects of Site 1202. Zhao et al used $\mathrm{U}_{37}^{\mathrm{K}^{\prime}}$ index to reconstruct the sea-surface temperatures (SSTs) for the past 28 kyrs. The sea-surface temperatures during the latest Quaternary (28 - $10 \mathrm{ka})$ varied around $24^{\circ} \mathrm{C}$ while the coldest intervals were during $19-18 \mathrm{ka}$ and $13-12 \mathrm{ka}$, corresponding to the Last Glacial Maximum (LGM) and the Younger Dryas, respectively. The SST rose from the LGM to the late Holocene values in two steps: the first one took place during 18 - 14 ka before a reversal during the Younger Dryas (14 - $12 \mathrm{ka}$ ), and the second began at $11.5 \mathrm{ka}$ and lasted until $7.0 \mathrm{ka}$. The second rise of SST is conspicuous by at least $4^{\circ} \mathrm{C}$ (from $22^{\circ} \mathrm{C}$ to $26^{\circ} \mathrm{C}$ ). Su and Wei examined the calcareous nannofossil assemblages of the past $13 \mathrm{kyrs}$. They found 
that major change in floral composition took place at $9 \mathrm{ka}$. Before $9 \mathrm{ka}$ the nannofossil assemblages were dominated by Gephyrocapsa spp. In contrast, after $9 \mathrm{ka}$, the deep-dweller Florisphaera profunda became more abundant at the expense of Gephyrocapsa. They interpreted that such a change implies that the Kuroshio re-entered into the southern Okinawa Trough at the same time.

Jean et al. extracted and identified indigenous bacteria strains from sediments of Holes A and D (down to $358 \mathrm{~m}$ ) of ODP1202. The extracted sulphate-reducing bacteria show strong phylogenetic affinity to Bacillus subtilis and Pseudomonas putida strains. Culturing experiments revealed that the isolated bacteria could survive under extreme conditions including temperatures higher than $45^{\circ} \mathrm{C}$, salinities up to $60-65 \%$ and $\mathrm{pH}$ values up to 10 . These bacteria can be adapted to either aerobic or anaerobic conditions and were capable of consuming $\mathrm{Fe}, \mathrm{Cu}^{2+}, \mathrm{Na}^{+}, \mathrm{K}^{+}, \mathrm{Mg}^{2+}, \mathrm{Ca}^{2+}$ and $\mathrm{F}^{-}$, yet no associated biogenic minerals have been identified. To assess fluid migration and water/sediment interactions at various depths in the holes, Huang et al measured major ions, concentrations of boron and boron isotopic ratios in pore water squeezed from ODP1202 cores. They found that the major ions and boron do not behave conservatively, and they are likely to be affected by sedimentary diagenetic processes. Apparently, boron released from clays is one of the most important boron sources to pore water, but other processes, such as precipitation of carbonates, low-temperature ash alteration and interaction with terrigenous sediments may also play important roles.

This issue by no means can include all the post-cruise study results of the ODP Site 1202. There are two other manuscripts being circulated among shipboard scientists. One describes the clay mineralogy and major elements of sediments of the top $120 \mathrm{~m}$ (Diekmann et al. MS), while the other reports the variation in Holocene magnetic relative paleointensity and inclination (Richter et al. MS). A synthesis of all of the research results should be available from the Scientific Result Volume of the ODP 195 in late 2005. It is clear that the publication of the above-mentioned papers is only the first step leading to a better understanding of the sedimentary records at ODP 1202. We expect to see more significant and spectacular findings coming up in the near future.

The publication of this issue marks a milestone of Taiwan's involvement in international scientific drilling programs. Here we dedicate this special issue to the international community of ocean drilling, and celebrate Taiwan's continuing participation in the new phase of the ocean drilling-the Integrated Ocean Drilling Program (IODP) in 2005. Without the continuous and enthusiastic support extended by the National Science Council, Republic of China, none of the above would be possible.

\section{REFERENCES}

Chang, Y. P., S. M. Wu, K. Y. Wei, M. Murayama, H. Kawahata, and M. T. Chen, 2005: Foraminiferal oxygen isotope stratigraphy and high-resolution organic carbon, carbonate records from the Okinawa Trough (IMAGES MD012404 and ODP Site 1202). Terr. Atmos. Ocean. Sci., 16, 57-73. 
Diekmann B., J. Hofmann, R. Henrich, U. Röhl, and D. K. Fütterer, 2005: Detrital sediment supply and signals of late Quaternary Environmental Changes in the Okinawa Trough off NE Taiwan (ODP Site 1202). (Submitted to Marine Geol.)

Huang, C. Y., Y. L. Chiu and M. Zhao, 2005: Core description and preliminary sedimentological study of Site 1202D, Leg 195, in southern Okinawa Trough.Terr. Atmos. Ocean. Sci., 16, 19-44

Huang, K. F., C. F. You, M. L. Shen, and H. L. Lin, 2005: Geochemistry of major constituents, boron and boron isotopes in pore waters from ODP Site 1202, Okinawa Trough.Terr. Atmos. Ocean. Sci., 16, 75-93.

Jean, J. S., T. Y. Chiang, K. Y. Wei, W. T. Jiang, C. C. Liu, and Y. P. Tsai, 2005: Bacterial activity and their physiological characteristics in the sediments of ODP Holes 1202A and 1202D, Okinawa Trough, Western Pacific. Terr. Atmos. Ocean. Sci., 16, 113-136.

Li, T., Z. Liu, M. A. Hall, S. Berne, Y. Saito, S. Cang, and Z. Cheng, 2001: Heinrich event imprints in the Okinawa Trough: evidence from oxygen isotope and planktonic foraminifera. Palaeogeog., Palaeoclimatol., Palaeoecolog., 176, 133-146.

Richter, C., A. Venuti, K. Verosub, and K. Y. Wei, 2005: Variations of the geomagnetic field during the Holocene: relative paleointensity and inclination record from the Southern Okinawa Trough (ODP Hole 1202B). (in prep.)

Salisbury, M. H., M. Shinohara, C. Richter, et al., 2002: Proc. ODP, Init. Repts., 195 [CDROM]. Available from: Ocean Drilling Program, Texas A\&M University, College Station TX 77845-9547, USA. Also available at <http://www-odp.tamu.edu/publications/ 195_IR/195ir.htm>.

$\mathrm{Su}, \mathrm{X}$., and K. Y. Wei, 2005: Calcareous nannofossils and variation of the Kuroshio Current in the Okinawa Trough during the last 13,000 years. Terr. Atmos. Ocean. Sci., 16, 95111.

Wei, K. Y., T. C. Chiu, and Y. G. Chen, 2003. Toward establishing a maritime proxy record of the East Asian summer monsoons for the Late Quaternary. Marine Geol., 201, 6779.

Wei, K. Y., H. Mii, and C. Y. Huang, 2005: Age model and oxygen isotope stratigraphy of Site ODP1202 in the Southern Okinawa Trough, northwestern Pacific. Terr. Atmos. Ocean. Sci., 16, 1-17.

Zhao, M., C. Y. Huang, and K. Y. Wei, 2005: A 28,000 year $\mathrm{U}_{37}^{\mathrm{K}}$ sea surface temperature record of ODP Site 1202B, Southern Okinawa Trough. Terr. Atmos. Ocean. Sci., 16, 45-56. 


\section{Guest Editors:}

Kuo-Yen Wei

Dept. of Geosciences, National Taiwan University

E-mail:weiky@ntu.edu.tw

Chi-Yue Huang

Dept. of Earth Sciences, National Cheng Kung University

E-mail: huangcy@mail.ncku.edu.tw

\section{Executive Guest Editor:}

Min-Te Chen

Institute of Applied Geosciences

National Taiwan Ocean University

E-mail:mtchen@mail.ntou.edu.tw 